\title{
Problems and Innovative Countermeasures of Construction Management of Water Conservancy Project
}

\section{Ruilin Tian}

Shanxi Province Water Conservancy Construction Engineering Co., Ltd., Taiyuan, Shanxi, 030006, China

\begin{abstract}
As a basic project related to the national economy and people's livelihood, the construction quality and efficiency of water conservancy projects are directly related to the development of social economy and the people's production and life. This paper mainly probes into the management problems existing in the construction process of water conservancy projects, points out the specific solutions and innovative countermeasures, hoping to promote the sustainable and stable development of water conservancy projects.
\end{abstract}

\section{Keywords}

water conservancy project; construction management; innovation strategy

\section{水利工程项目施工管理问题及创新对策}

\section{田瑞林}

山西省水利建筑工程局有限公司，中国・山西太原 030006

\section{摘 要}

作为关系着国计民生的基础工程，水利工程项目的建设质量和建设效率直接关系着社会经济的发展和人民的生产生活。本文 主要针对水利工程项目施工过程中存在的管理问题进行探究，指出具体的解决方法和创新对策，希望能够促进水利工程持续 稳定的发展。

\section{关键词}

水利工程项目；施工管理；创新策略

\section{1 引言}

随着社会经济的不断发展和人民生活水平的提高，人们 对水利工程项目的建设质量和建设水平的要求越来越高, 原 有的水利工程项目建设方法和管理策略已经无法满足当前日 益增长的水利需求。从当前现有的水利工程项目施工管理情 况来看, 仍然存在各种各样的问题, 影响水利工程功能的发挥。 因此, 必须要加强对管理问题的探究, 采取针对性的措施进 行解决，提高水利工程整体的施工质量。

\section{2 当前水利工程项目施工管理过程中普遍存在} 的问题

\section{1 质量控制问题}

质量管理工作是水利工程项目建设过程中最为关键的工 作, 对后期建筑的应用具有至关重要的作用。因此, 必须要 加强对水利工程项目的施工管理以及质量管理工作, 合理的
利用质量控制管控体系，要求施工企业的管理人员具备专业 的质量控制知识和意识，并将质量管理效率作为员工职业水 平的考核标准，提高员工质量控制的积极性和主动性。在企 业内部重拾起施工质量管理工作，不能只追求眼前的利益和 短期的经济效益, 而忽略了整体的施工质量, 要从企业的长 远出发，加强对施工工程项目的控制，将施工质量摆在企业 管理的首位。 ${ }^{[1]}$ 其次, 还需要加强对施工管理方法的控制与 研究，建立起安全可靠、行之有效的机制。并在商业设计方 面进行细化，注意金融风险的问题，有效规避资金筹集风险，

加强签订的合同条约和施工团队建设的管理，严格落实质量 管理工作和一些对应的检测工作，保证水利工程项目施工管 理能够严格按照相关标准和制度来开展。

\section{2 缺乏可靠完善的管理制度}

当前中国是一个工程项目在管理过程中存在制度不科学、 不完善的问题，难以充分发挥制度的约束作用，导致水利工 